\title{
THE FRANK WATSON BOOK PRIZE IN SCOTTISH HISTORY
}

The Frank Watson Book Prize for the best book or monograph published on Scottish History in 2017 and 2018 has been awarded to:

Timothy J. Shannon, Indian Captive, Indian King: Peter Williamson in America and Britain (Harvard University Press, 2018). ISBN: 9780674976320.

We are delighted to honour Dr. Shannon's work alongside the many esteemed recipients of this prestigious prize.

Impressed with the range and quality of the submissions last year, the Judging Committee would also like to congratulate Dr. Aaron Allen as "honorary mention" for the Frank Watson Prize, and Dr. Valerie Wallace for the "best first book" published in 2017/2018.

Aaron Allen, Building Early Modern Edinburgh: A Social History of Craftwork and Incorporation (Edinburgh University Press, 2018).

Valerie Wallace, Scottish Presbyterianism and Settler Colonial Politics: Empire of Dissent, Cambridge Imperial \& PostColonial Studies Series (Palgrave Macmillan, 2018)

The judges of the Frank Watson Book Prize wish to thank all those who entered the competition. 
The Guelph Centre for Scottish Studies is currently accepting submissions for the Frank Watson Book Prize for the best monograph and/or original work on Scottish History published in 2019 or 2020 . We welcome all submissions of monographs, edited collections, and/or book-length original works on Scottish History published between 1 January 2019 and 31 December 2020. The Prize consists of a cash award, an invitation to present a plenary lecture, and permission to advertise success in the competition.

Authors, publishers, or other sponsors should submit three copies of books for consideration by 30 June 2021 to:

Professor Kevin James

Scottish Studies Foundation Chair

The Centre for Scottish Studies

Department of History

University of Guelph, Guelph, ON, Canada

N1G 2W1 